\title{
NEWS OF THE ASSOCIATION
}

\author{
MESA SECRETARIAT
}

I. William Zartman has expressed the desire to resign as Executive Secretary. Although there is no term to the office, the Executive Secretary has long felt that a decade was a sufficiently long time for one person to hold his position and to accomplish projected goals. He has kindly agreed to remain in office until the end of the calendar year, or the end of the academic year 1976-77, whichever is more convenient to MESA.

The Board of Directors has the responsability of selecting the Executive Secretary, since selection of this official also involves choice of the institution willing to offer office space and other facilities to MESA for its Executive Secretariat.

The Board of Directors announces this development now in order that suggestions may be received from the membership.

The Board of Directors also solicits from the proper official of academic or other appropriate institutions proposals to accommodate the MESA Executive Secretariat. A statement describing the facilities now being offered by New York University is being prepared. The information in this statement, the substance of which will be made available to other academic institutions submitting formal proposal, will be used to guide the Board of Directors in the choice of the next Executive Secretary and the site of the Executive Secretariat.

L. Carl Brown

President, MESA

\section{MESA NOMINATING PROCEDURE}

Professor Ernest Dawn has agreed to serve as Chairman of the ad hoc Committee, as authorized by the last Business Meeting of November 21 , 1975, to review MESA nominating procedures. The Committee invites comments from MESA members concerning the nominating procedure. All suggestions should be sent directly to Professor Ernest Dawn, Department of History, University of Illinois at Urbana-Champaign, 309 Gregory Hall, Urbana, Illinois 61801.

\section{OUTREACH PROGRAMS}

The MESA Committee on Pre-Collegiate Education is collecting information on all types of Outreach Programs and any activities relating to community projects and elementary and secondary schools. All individuals and/or centers involved in such programs are requested to forward pertinent information to Ms. Barbro Ek, Center for Middle East Studies, Harvard University, Cambridge, Massachusetts 02138 .

\section{THE MIDDLE EAST IN PAPERBACK}

David Littlefield has agreed to prepare for MESA a new edition of "The Middle East in Paperback" which will cover all aspects of the Islamic period of the Middle East and which will include paperback publications in all Western languages. MESA members are invited to send contributions of annotated items including, if possible, bibliographic information from a Library of Congress card. Send contributions to David Littlefield, 6809 Fifth Street, N.W., Vashington, D.C. 20012 . 


\section{VISITING SCHOLARS PROGRAM, SPRING 1976}

Professor André Raymond of the Université de Provence (AixMarseille) and Professor Ozer Soysal of the Institute of Librarianship of Ankara University have accepted MESA's invitation to lecture for three to six weeks at leading Middle East centers in the U.S. and Canada. Professor Raymond will be here April 6 through May 8 and Professor Soysal's dates are April 14 through May 30 . Summaries of their curriculum vitae are given below. For further information, write the MESA Secretariat, New York University, Hagop Kevorkian Center for Near Eastern Studies, Washington Square, New York, NY 10003.

\section{ANDRE RAYMOND}

Licence et diplôme d'Etudes Supérieures d'Histoire de la Faculté des Lettres de Paris, 1945.

Agrégation d'Histoire, 1947.

D. Phil. de 1'Université d'Oxford, 1954.

Doctorat Es-Lettres, Université de Paris, 1972.

Director of the Institut Francais d'Etudes'Arabes de Damas, 1969-75.

Co-director of the Bâlis/Meskeneh archeological mission in the Euphrates region, 1970-74.

Presently Professor of History at the Université de Provence (AixMarseille I).

Recent publications: Artisans et Commercants au Caire au XVIIIème siècle, I.F.D., Beirut, 2 volumes, 1974; "Problèmes urbains et urbanisme au Caire aux XVIIème et XVIIIème siècles" in Actes du Colloque International sur 1 'Histoire du Caire, DDR, 1973; "Les grandes epidemies de peste au Caire aux XVIIeme et XVIIIeme siècles" in Bulletin d'Etudes Orientales, Damascus, 1972; "La population du CaIre du XVIe au XVIITe siecle", paper delivered at the Congrès d'Histoire Economique, Copenhagen, August 1974, and forthcoming in J.E.S.H.O.; Les marchés du Caíre, annotated translation of MaqrizI, in collaboration with G. Wiet, I.F.A.O., for thcoming .

Suggested lecture topics: Egyptian society and economy from the 16 th to the 19 th centuries; The cities of the Ottoman Empire from the 16 th to the 19 th centuries.

\section{OZER SOYSAL}

B.A., 1955-59, Ankara University, Faculty of Letters, Chair of Library Science.

Ph.D., 1964, Ankara University, Faculty of Letters, Chair of Library Science.

Editor of 'Yeni Yayinlar, Aylik Biblioyografya Dergisi/New Publications, Monthly Bibliographical Journal, (1972-75).

Presently Professor at the Institute of Librarianship, Faculty of Letters, Ankara University.

Principal publications: Contemporary Education and School Libraries in Turkey, 1969; School Libraries: A Historical Study and Regional Evaluation of School Libraries in Ankara, 1969.

Member of Turkish Librarians Association.

Member and President of the Association of the University Library School Graduates (1970-75).

Suggested lecture topics: The current National Bibliography of Turkey: its brief history and development; The current Turkish National Bibliography and some recent bibliographical contributions in Turkey. 
The following new members have joined MESA since October 1975. In some cases, former student members have become Regular members or Fellows. Student members are urged to contact the MESA Secretariat upon receiving their $\mathrm{Ph}$.D., so that their membership category can be updated. Any member may have his membership category revised by filling out a new application form available from the MESA Secretariat.

\section{Fellows}

Syed Barakat Ahmad, High Commissioner for India, Trinidad

Hossein Askari, International Business and ME Studies, Texas University Fuad Baali, Sociology, Western Kentucky University

Ronald W. Casson, Anthropology, Duke University

Constance Cronin, Anthropology, Arizona University

Raphael Danziger, History, Haifa University

Marceau Gast, Anthropology, Centre National de la Recherche Scientifique Gavin R.G. Hambly, History, University of Texas at Dallas

Wafik A. Hassouna, Health and Social Planning, Inst. of National

Planning, Cairo

Suad Joseph, Anthropology, Hofstra University

John G. Kennedy, Anthropology \& Psychiatry, UCLA School of Medicine

Dennis E. Knox, History, Boston College

Bernard A. Lalor, Membership Secretary, Oriental Institute, Chicago

Consuelo Lopez-Morillas, Romance Languages, Ohio State University

Mona N. Mikhail, Literature, New York University

Bard E. O'Neill, Political Science, USAF Academy

Munibur Rahman, Literature, Oakland University

Thomas M. Ricks, History, Georgetown University

Paul E. Walker, History, Smithsonian Institution

Abdul Hamid Zein, Anthropology, Temple University

\section{Regulars}

Amat Abidin, Islamic History, Jalan University, Malaysia Stephen D. Auerbach, Anthropology, University of Wisconsin-Milwaukee Ralph M. Coury, Jr., History, American School in Tangiers John T. Cummings, Economics, Tufts University/Lincoln Filene Center Susan Schaefer Davis, Anthropology, Trenton State College Grant Michael Farr, Sociology, Portland State University Kamel M. Gab-A11ah, Library Assistant, Cooper Union College Library Niki Gamm, Research Assistant to Dean of Continuing Studies, Simon Fraser University

Edward S. Haynes, History, Kansas State University

Raymond A. Hinnebusch, Political Science, University of Pittsburgh Seymour P. Lachman, History \& Politics of Education, CUNY

Robert L. Lembright, History, Madison College, Harrisonburg, Va . John E. Long, Religion, Western Kentucky University

François-Auguste de Montequin, Art History, Hamline University Thomas J. Martin, Literature, St. Andrews University, Scotland Natalie K. Moyle, Slavic Studies, University of Virginia

Taysir Nashif, Researcher \& Translator, Libyan Arab Republic Delegation to the U.N.

Yves Schemeil, Political Science, Fondation Nationale des Sciences Politiques, Paris

Michael B. Schub, Arabic, Cornell University

Maurie Sommer, Geography, Columbia University

Barbara Hooper Sude, History, Western Carolina University

Muna Vaki1, Community Education Coordinator, NE Center, University of Washington

Frithjof R. Wannebo, Education, Bahrain School 


\section{Associates}

Raymond W. Andrews, Analyst, Washington

Thomas Casse11, Contract Analyst, Northwestern University

Bechir Ben Yahmed, Publisher and Editor, Jeune Afrique

Cynthia M. Chambers, Free Lance Consultant

Robin F. Keil, Officer, U.S. Navy

Howard Koch, Jr., Research Associate, Hoover Institution

Ann Mosely Lesch, ME Representative, American Friends Service Committee

Christopher A. Mock, Consultant, Implementation of Grain Fortifica-

tion Progrim, Tunisia, Harvard School of Public Health (AID)

Richard F. Wood, Marketing Supervisor, Boeing Aerospace Company

\section{Students}

S. Ali Al-Marashi, Near Eastern Languages, University of Chicago Amir Hassan Ahanchian, Political Science, Purdue University Jon W. Anderson, Anthropology, University of North Carolina Muriel Atkin, History, Yale University

Sanaa M. Azmi, NELL, Yale University

Jeannie Balison, History, Portland State University

Michael Baran, History, University of Michigan

Ross Brann, NELL, New York University

Jill S. Cowen, Fine Arts, New York University

Sherry L. De Mandel, History, San Francisco State University

Salwa El-Shawan, Ethnomusicology, Columbia University

Mohammad H. Faghfoory, Political Science, University of Wisconsin Stephen C. Fairbanks, History, University of Michigan

Nabiel J. Fareed, Political Science, Washington State University Warren Stuart Feldman, High School student

Mary Russell Gault, Comparative Literature, Harvard University James Norman Geh1har, Persian \& Turkish, University of Edinburgh George J. Giacaman, Philosophy, SUNY-Buffalo

Erika H. Gilson, Turkology, University of Pennsylvania

Mary-Jo Del Vecchio Good, Sociology, Harvard University

Jerrold Green, Political Science, University of Chicago

Edward Hamburg, Political Science, University of Chicago

Kay Hardy Hanson, Linguistics/Literature, University of Minnesota Syed F. Hasnat, Political Science, University of South Carolina Howard Horowitz, Political Science, New York University William S. Kritzberg, History, New York University Gabriel Lahood, NELL, New York University/Princeton Theologica1 Seminary

Robert J. Latowsky, Anthropology, SUNY-Binghamton Kathleen Modrowski, Anthropology, Université de Paris Norman Douglas Nicol, History, University of Washington Dilworth B. Parkinson, Linguistics, University of Michigan William R.C. Phelps, History, University of Michigan Nadine F. Posner, Philosophy, Boston University Nancy Pressman, NELL, New York University

Barbara Allen Roberson, History, London School of Economics Jonathan $H$. Rodgers, Linguistics, Yale University Joseph W. Ruzanski, Political Science, New York University Karon D. Salch, History, University of Texas Martin W. Sampson III, Political Science, Indiana University Phyllis Simpson, Altaistics, Indiana University Maria E. Subtelny, Literature, Harvard University Lisa Taraki, Sociology, SUNY-Buffalo Kathleen S. Taylor, History, University of Arizona Anthony $K$. Tuft, NE and African Languages, UCLA Daniel M. Varisco, Anthropology, University of Pennsylvania Charles F. Vittor, Jr., NE Studies, Berkeley Donald Whitcomb, Anthropology, University of Chicago Fariba Yektai, Economics, New School for Social Research, New York Robert F. Zeidner, History, University of Utah Madeline Zilfi, History, University of Chicago 